\title{
Trade reform and development
}

\section{Ligang Song *}

Trade system reform has been an important component in the overall strategy of reforming the economic system in China. Tremendous progress has been made over the past twenty years, but much more needs to be done in setting up a more open, efficient and transparent trade system, in line with the requirements of the World Trade Organization (WTO).

\section{Historical legacy}

China's trade system was a highly centralised and controlled planned system during the pre-reform period (1958-78). The main features of this type of trade system were ${ }^{1}$

- foreign trade was conducted strictly according to central planning, which covered areas such as trade procurement, imports, exports and balance of foreign exchange-the State Planning Commission and Ministry of Foreign Trade were the key players in drawing up the plan for trade with an objective to fulfil the government's overall plan

- a centralised accounting system was run through the Ministry of Foreign Trade and the Ministry of Finance-under this system, producers and trading companies (handling both imports and exports) were not responsible for profits or losses incurred in their production and trading activities 
- trade (both imports and exports) was handled exclusively by state trading companies with numerous local branches which were highly specialised and monopolised

- a planned price system was used for conducting foreign trade. It virtually broke the link between domestic and international pricesfor example, the procurement of export goods, and domestic sales (distribution) of imported goods were conducted according to domestic planned prices whereas goods were exported and imported based on international prices

- the state managed, monitored and controlled trade activities largely through administrative means such as tariff protection and import controls

- foreign exchange transactions were also centrally controlled and handled exclusively by the Bank of China-trading companies handed over all their foreign exchange earnings to the state; demands for foreign exchange by domestic users for imports were met by allocating foreign exchange to these users according to the plan

- the government implemented a policy of balancing foreign exchange-the renminbi (RMB) exchange rate became an accounting tool for planning and its determination was not associated with the demand for and supply of foreign exchange. This tended to lead to an overvalued RMB exchange rate (Shi 1998:158).

The major shortcomings and potential consequences of this highly centralised trade system included

- by limiting competitive pressure on domestic producers, the old trade system tended to restrict the development of exports. At the same time, there were always tendencies for China to import more due to excessive demand for imported goods, leading to a persistent shortage of foreign exchange, subsequent exchange controls and an overvalued exchange rate

- since neither producers nor exporters (trading companies) were responsible for profits and losses, trading activities tended to be inefficient, not very innovative and there was a lack of incentives to reduce costs

- due to the lack of incentives for enterprises to reduce costs, the losses on exports became apparent and the government was continually required to provide subsidies and various kinds of trade protection measures; distortions occurred 
- because goods were traded according to the plan, there were no policy settings aimed at boosting foreign trade, particularly exports, or exploring gains from trade through close integration with the world market

- because goods were traded through monopolised trading companies and based on distorted prices, enterprises suffered from a lack of exposure to competition and there was no quick feedback from world market in terms of changing market conditions for exports. (Subsequently enterprises had little incentive to upgrade their production facilities or change the composition of trade. This lack of connection between production and trade in turn hampered enterprises' prospects for competing in the world market.)

- a high degree of protectionism and an overvalued exchange rate jointly reflected China's adoption of import substitution strategies during the pre-reform period-inwardly-oriented development strategies in which 'trade and other incentives were biased in favour of production for the domestic market and against production for export' (Lardy 1992:7)

- the highly centralised trade system produced large numbers of groups with vested interests in controlling and monopolising production and trading activities-they became strong forces in resisting reform.

Realising the shortcomings of the old system and their consequences, China embarked on reform to its economic system, including the trade system, towards the end of the 1970s. Reform has substantially reduced the extent of anti-export bias and allowed the Chinese economy to become more deeply integrated with the world economy.

\section{Stages of trade reform}

In the context of the overall economic reforms and institutional changes that started in the late 1970s, the reform of the trade system in China has gone through four stages, each with its own emphasis and associated problems. ${ }^{2}$ The reforms have moved from being experimental to being more in line with the requirements of the WTO, and the main aim of external reform has been 'to scale back the scope of trade planning and to shift to a reliance on market mechanisms for determining the pattern of imports and exports (Tseng et al. 1994:4). 


\section{Stage one: 1979-84}

The first stage of trade system reform in China began at the same time as the general reform of the economy. The aim of this initial stage was to explore the possibility of reforming the highly centralised trading regime inherited from the Soviet-style central planning system. Various experiments were undertaken at this stage of reform including decentralisation of foreign trade authority by relinquishing the monopoly on foreign trade it had exercised since the mid 1950s (Lardy 1992:39). The right to conduct foreign trade was gradually granted to provinces, municipalities, industrial sectors and enterprises.

The government also experimented with more diverse forms of trade including processing trade, compensation trade and border trade. ${ }^{3}$ As an experiment to introduce foreign capital into the economy and to gain the experience of conducting production (management), trade and other business activities in line with standard practice, special economic zones were established during this period. To manage the new forms of trade that were not covered by the state plan, the government adopted the import and export licensing system and a number of large enterprises were given the right to conduct foreign trade directly. Furthermore, the foreign exchange retention system was established to provide local governments and enterprises with greater incentives to export.

The reform experiment at this initial stage was successful in that it took the first but very important step of reforming the whole trade system. In particular, the foreign trade planning system began to be transformed and the monopoly power of the foreign trade corporations under the Foreign Trade Minister was gradually weakened (Li 1996:81). However, owing to resistance to the reforms, a lack of experience and human skills needed to manage the reforms, and the problems that emerged in the process (such as the emergence of chaotic trading activities resulting from uncoordinated approaches to reform), the reform program achieved only limited success.

One important outcome of this initial period of reform was that the experience made the government realise that reforming the trade system would be a long and painful process and that it might be necessary to take a step-by-step approach, closely monitoring the results of each step and then making policy adjustments accordingly. This approach was crucial for conceiving and designing subsequent reforms, not only in trade but also in other areas of the economy. However, a side effect 
of such an approach is that the elements of the traditional structure have, in many ways, frustrated and hampered the reform efforts.

\section{Stage two: $1985-86$}

In the second stage of reform ${ }^{4}$ the government adopted a reform program aimed at separating government functions from enterprises, simplifying administrative procedures for approving imports and exports, adjusting tariff rates to increase competition and further decentralising power to enterprises.

Under this program, experiments in reforming the planning and accounting system were also carried out and attempts were made to break the planning framework in order to create more direct links between production and trade. From the beginning of 1985, China also abandoned the internal exchange settlement rate, which was introduced in 1981. A 'managed floating' exchange rate system was established in which exchange rates were predominantly adjusted according to changes in both domestic and international prices.

To accommodate the need for changing the management of trade from direct administrative control to indirect means, China also established a system of export tax-rebates, a fund for encouraging exports and differential tariff rates for exports and imports. China's Tariff Law was comprehensively modified during this period (Shi 1998:162).

Due to these reform programs, China entered a stage where compulsory planning, indicative planning, and market adjustment mechanisms were all in place at the same time.

As had happened during the first stage of the reform program, the measures taken at the second stage represented one more step towards the liberalisation of the trade system. However, reform at this stage also encountered some difficulties. For example, enterprises could not be truly independent because of their close relationship with the government, and price signals could not fully function because of the operation of a two-tier price system. As a result, enterprises were not wholly responsible for profits and losses in conducting foreign trade.

What the government learned from this stage of reform was the importance of reforming the system in a comprehensive manner. But owning to various difficulties-particularly those existing in the relationship between the government and enterprises-and, more importantly, because of the benefits of the reform measures-namely 
a rapid increase in trade- the government decided to continue its stepby-step approach to reforming the trade system rather than implementing any sudden changes.

Up to this stage, the reform measures had predominantly been aimed at changing the basic structure of the old system and not at conforming to the requirements of the General Agreement on Tariffs and Trade (GATT). However, the government realised the potential benefits to the reform process of joining GATT and believed that the time had come for China to apply for re-entry. In July 1986, China officially launched its application. Subsequently, reforming the trade system in accordance with the requirements of GATT became the main task in the next stage of the reform program.

\section{Stage three: 1987-90}

The key reform measure adopted at this stage was the general implementation of the 'contract system' in both trading and production enterprises in the export sector. The contract system was also applied to the relationship between local and central governments from 1988. The system included contracts between enterprises, trading companies, local governments, and the central government, in the areas of foreign exchange earnings, quotas of foreign exchange earnings handed over to the state, the reduction of export subsidies and responsibility for export profits and losses.

Under the contract system, though obliged to fulfil the plan for exports, foreign exchange, and total profits and losses in relation to the central government, local governments had the autonomy to decide on commodity mix, quantities, prices for exports and means of conducting trade. The central government was still responsible for profits and losses incurred by those who traded within the central plan, however the local governments were accountable for those who traded outside the plan. Local general specialised trading companies no longer had direct links with central finance, but were associated with local finance (Shi 1998:163)

To reflect the changes to the trade operation system, commodities were divided into three broad groups: a few resource products that were handled by those specialised trading companies; commodities that were subject to licensing and quotas and dealt with through local trading companies; and commodities that were allowed to be traded 
freely (Shi 1998:164). This division helped clear confusion about policy settings in which particular commodities were subject to trade, but a certain proportion of commodities were still traded under planning and administrative controls. Thus, this division of commodities was abandoned by the government at the next stage of reform. By then, only a few key commodities were handled by the state and all other commodities were traded freely by various trading companies and producers.

Other changes implemented at this stage of reform included: the central government no longer providing subsidies for price differentials, increased proportions of foreign exchange being retained by local governments, and the government allowing trading companies and enterprises to trade their retained foreign exchange at market prices in foreign exchange swap markets.

These reform measures touched upon the issues of operational mechanisms within enterprises and the role of local governments in managing foreign trade. The reforms themselves, therefore, had important implications for the government's attempts to build up a modern enterprise system to be adopted at a later stage of its reform program. ${ }^{5}$

One result from this stage of reform was a rapid expansion of trade owing to the strong production and trading incentives for enterprises, trading companies, and local governments that resulted from the contract system. However, there were some problems associated with the reforms, the key one being that a favourable environment in which fair competition could be conducted had not been created. The other area in which reform had not made much progress was in the import system. These problems were addressed at the next stage of trade system reform.

\section{Stage four: 1991-93}

In line with the policy on the reform of SOEs, the main objective of the reform program at this stage was to allow enterprises to be fully responsible for their profits and losses in order to equip them with a mechanism for competing both domestically and internationally on a fair basis. The measures adopted included phasing out export subsidies, narrowing the regional differences in foreign exchange retention rates, giving more power to enterprises to use foreign exchange, and using 
exchange rates and tariff rates to adjust trade activities. Efforts had also been made to raise the quality of export products and adjust the commodity structure of China's imports and exports. The government's intention was to create a truly competitive environment for enterprises involved in foreign trade, similar to that in which firms in other countries operated.

China also speeded up its efforts to re-enter GATT by substantially reducing the volume of exports subject to planning, further improving the export-licensing system by increasing its transparency, and deepening reform of the enterprise system.

Another important reform that resulted from conforming to the requirements of GATT was the reform of the import system, which had lagged behind reform of the export system. The import system in China was highly centrally planned, using import planning, administrative approval, import licenses, import price determination, exchange controls, and import tariffs to control import activities. The general results of these measures were nontransparency in import transactions and overprotection of some domestic industries. The need to reform its import system became even more obvious when China set its sights on re-entering GATT.

China initiated the reform of its import system at the beginning of 1992 with a unilateral reduction of tariff rates for a wide range of commodities, abandonment of import adjustment taxes (effective from April 1992), reduction of the coverage of import licensing, ${ }^{6}$ and a reexamination and subsequent abandonment of the internal documents for import management and control. ${ }^{7}$ While reforming the old import system, China aimed to establish a modern import management system, characterised mainly by reliance on tariffs and exchange rates to adjust imports, compatible with normal practice in other countries and consistent with the rules of GATT. The measures undertaken to achieve this goal included further reduction of the coverage of mandate planning for imports, abandonment of the system of administrative approval for imports, and further improvement of the import-licensing system, which entailed increasing its transparency and fairness.

Compared with the reforms of the previous stage, the new reform program went one step further in reforming China's trade system. More importantly, the reforms made the trade system increasingly consistent with the requirements of GATT. However, structural problems existing at a deeper level remained. For example, the two-tier currency system, under which foreign exchange transactions were conducted according to both the official rate and the rate prevailing in so-called foreign 
exchange swap centres, was still in place. This system hindered further deepening of the reform of China's trade system.

In principle, the two-tier exchange rate system should have been abolished but in reality there were many difficulties associated with abolishing it. By creating more distortions the system tended to discourage exports and imports, induce a scarcity of foreign exchange, increase the secondary market price of foreign exchange, and lower real income (Martin 1990). The main difficulty in reforming the currency system was that the system itself was tied up with the old institutional framework to which the relationship between the government and enterprises was intrinsically linked. Another difficulty was that official exchange rates were far from market equilibrium level. This meant that there were some preconditions for taking the steps necessary to reform the exchange rate system.

Although there were pros and cons for domestic enterprises-for example, unified exchange rates could bring an end to the effective subsidy given to the state enterprises that were allowed to buy foreign currency at the cheaper official rate-the potential gains for the whole economy from abolishing the system could be substantial. Most important, the reform measures taken at previous stages of the reform process had laid the foundations for the government to take more drastic measures in reforming its trade system. Two examples stand out. One was that the majority of enterprises had been trading based on market rather than official exchange rates, reflecting that the bond between government and enterprises had further loosened. The other was that the government had adopted a series of measures in adjusting official exchange rates towards more market-determined equilibrium prices. This has been characterised by a gradual and steady depreciation of the RMB during the past 15 years.

These examples suggest that the aforementioned preconditions had been more or less satisfied after several rounds of reforms. Reformation of the two-tier currency system became one of the most important targets of trade system reform in 1994.

\section{Stage five: 1994 onwards}

The fifth stage of reform is ongoing. ${ }^{8}$ Characterised by its comprehensiveness in reforming taxation, finance, and the currency system, this stage has been the most dramatic so far in reforming the 
trade system. The key measure adopted was the reform of the system of controlled exchange rates. Its aim was to create a system of managed floating exchange rates based on market forces and the gradual transformation of the RMB into a convertible currency.

The government abandoned the former two-tier exchange rate system - the foreign exchange certificate (FEC) - and unified the RMB's exchange rates at the beginning of 1994 by cutting the official exchange by 33 per cent and beginning to phase out FECs in an effort to bring the system up to world standards. ${ }^{9}$ This move, a positive step in China's application to rejoin GATT, was welcomed in foreign business circles. Previously, foreign investment was calculated in RMB at the official rate, while profits were repatriated at the swap market rate, which tended to follow the currency's black market value. After the merging of the exchange rates, the government also abolished the exchange retention system and the system of turning over foreign exchange earnings to the government.

The unified exchange rate is determined in an interbank market. In April 1994, the China Foreign Exchange Trading System (CFETS) in Shanghai, a nationally integrated electronic system for foreign exchange trading, became operational. As a national market, the CFETS has largely eliminated the fragmentation of the foreign exchange market that resulted from the tendency of local authorities to protect local holdings of foreign exchange (Tseng et al. 1994:8). The CFETS is also proof that China has formed a market-driven mechanism for determining RMB exchange rates.

To institutionalise the reformed trading practices and speed up its campaign to re-enter GATT, China issued its first trade law in May 1994, which was designed to fulfil the two basic demands of GATT: transparency and uniformity. The trade law emphasises market measures over administrative means for the management of trade. With the new trade law, a uniform, fair, and free trade policy is expected to take shape in China.

From December 1996, the RMB has been made convertible under current account. Under the new system, foreign exchange for trade transactions can be purchased from designated banks upon presentation of valid trading documents. This change, together with the exchange rate unification which took place two years earlier, led to a more market-based exchange rate system and contributed to the rapid 
development of exports and imports through more efficient use of resources and increased international competitiveness.

Reform in other areas continued and is ongoing. In particular, the government eliminated all remaining mandatory trade planning in 1994 and gradually established an indirect mechanism for managing foreign trade. More enterprises have gained rights for conducting direct trade. ${ }^{10}$

To realise the ultimate goal of establishing a trade registration system under which official approval for conducting trade would not be required, in February 1997 the Ministry of Foreign Trade and Economic Cooperation (MOFTEC) issued a regulation for implementing a registration system for enterprises operating in the special economic zones. ${ }^{11}$ Furthermore, tariffs and the commodity scope of trade quotas and licensing continued to be reduced.

\section{Achievements}

Trade system reform over the past two decades has made great achievements in trade and more broadly.

\section{Reducing anti-export bias}

The success of trade system reform has provided convincing evidence that trade liberalisation contributes to trade expansion and improvements in welfare. Several multi-country studies, for example Harrigan and Mosley (1991) and Papageorgiou et al. (1991), offer some support for the view that liberalisation and exports are related. The main proposition behind these studies is that liberalisation reduces anti-export bias and thus provides an environment conducive to expansion.

Reducing anti-export bias in China has been achieved through a series of reform and trade policies aimed at eliminating the distortions that resulted from extensive government restrictions on trading activities. The reform programs have become increasingly comprehensive over time and have been implemented gradually.

Reducing anti-export bias has had an enormous effect on trade. Total trade increased from US $\$ 20.6$ billion in 1978 to US $\$ 325.1$ billion in 1997 , with an average growth rate of 14.8 per cent per annum. Exports increased at an average annual rate of 15.8 per cent and imports at an average annual rate of 13.7 per cent during this period. Trade structure continued 
to shift in favour of manufactured commodities. The share of manufactures in total exports increased to 87 per cent in 1997 compared with only 49.7 per cent in 1980. Official foreign exchange reserves increased from US $\$ 0.8$ billion in 1979 to US $\$ 140$ billion in 1997 . China has become the largest recipient of foreign capital among developing countries in recent years and became the 10th largest trading nation in the world in 1997, having risen from 29th in 1978. The Chinese economy has become deeply integrated with the world economy.

\section{Changing role of the state}

The centralised planning of imports and exports has been replaced by government guidance and indirect controls (Tseng et al. 1994:4). ${ }^{12}$ Export incentive schemes characterised by a high degree of decentralisation (and government preferential treatments) were first applied to the special economic zones, then the coastal areas and later other parts of the country. By the mid 1990s, thousands of big SOEs had direct trading rights and non-state sectors, particularly foreign firms, are playing an increasing role in China's foreign trade. To prevent the adverse effects of the tariff structure on the export sector and provide more incentives for exports, the government also adopted a system of duty exemptions and tax rebates for exporters. As a result, an indirect trade management system is taking shape in China.

\section{Table 4.1 Share of goods sold at state-fixed prices, 1978-93} (per cent)

$\begin{array}{cccc}\text { Year } & \text { Retail commodities } & \text { Agricultural goods } & \text { Capital goods } \\ 1978 & 97 & 94 & 100 \\ 1992 & 10 & 15 & 20 \\ 1993 & 5 & 10 & 15\end{array}$

Source: World Bank, 1997e. China Engaged: integration with the global economy, World Bank, Washington, DC:Table 1.1. 


\section{Tariff reduction}

Both tariffs and non-tariff barriers have been gradually reduced. For example, from the tariff reduction announced at the November 1995 meeting of the Asia Pacific Economic Cooperation (APEC), which became effective in 1996, tariff cuts reduced the trade-weighted average tariff from 28.1 per cent to 19.8 per cent and the unweighted average from 36 per cent to 23 per cent in 1996, and the latter was further reduced to 17 per cent in October 1997 as the government accelerated the pace of reform (World Bank 1997e:14).

As part of the liberalisation program, import licenses and quantitative import restrictions (QRs) have been removed from a wide range of commodities since the early 1990 s. For those commodities still subject to import controls, such as machinery and electronic equipment, new regulations for their administration were implemented that narrowed the scope of controls and simplified import procedures (Tseng et al. 1994:10).

\section{Price linkage}

A link between domestic and international prices has been established through price system reforms (Chai and Sun 1993:5). Such a link was virtually nonexistent in China before 1978. Price reforms since the mid 1980s mean that domestic prices for more than 90 per cent of imported goods are now linked to (and affected by) world prices. This link may imply a narrowing of price differentials, although trade barriers and other costs continue to drive a wedge between the two (World Bank 1997e:8).

\section{Comparative advantage}

The self-sufficiency policy and associated distortions in the pre-reform period prevented China from exploiting its comparative advantage in the market, particularly in the area of labour-intensive products. The increasing degree of marketisation as a result of institutional changes and trade liberalisation led to the conformity of China's trade pattern to its comparative advantage (Zhang 1993; Song 1996a). Such conformity has been the main reason for the rapid changes in the commodity composition of China's foreign trade, in particular its exports of labourintensive products. 


\section{Trade, investment and standard of living}

Trade reform and liberalisation, accompanied by a shift of development strategy away from heavy industries, completely altered the relationship between foreign trade, investment and the standard of living. In the pre-reform period, foreign trade acted as a mechanism for transferring resources from the consumer goods sectors, including agriculture, to the industrial sector through the selling of agricultural and primary products and the purchase of manufactured goods. Because the increased output comprised mainly producer goods, the growth of foreign trade and investment was limited by the extent to which the standard of living could be lowered. Therefore, the sharp rises in investment and foreign trade at that time often proved unsustainable (Hsu 1989:15).

The economic climate is fundamentally different now. Investmentincluding foreign direct investment (FDI)-boosts foreign trade which in turn helps sustain an increased scale of investment and capital formation in the Chinese economy each year. More importantly, the link between and growth of trade and investment has been accompanied by an extraordinary improvement in the standard of living of the Chinese people. The significance of this for China's foreign trade and investment is evident.

\section{Opening of financial services market}

Gradual opening of its financial service market is China's commitment to liberalising its services trade and the government has been adopting measures to implement the liberalisation plans in recent years. For example, by 1997 the government had approved nine foreign banks to deal with RMB transactions in the Shanghai Pudong area, marking the beginning of a gradual opening of China's financial sector to foreign competition and a new phase of China's financial system reform. In July 1997, the government approved the first joint venture trading company in Shanghai and by the end of the same year there were four such trading companies operating in Shanghai and Shenzhen. Also in 1997, the government issued a regulation allowing foreign asset assessment institutions to set up joint ventures or joint cooperation for asset assessment in China (Zhao 1998:198). 


\section{Economic benefits}

The economic benefits generated by the openness of the economy are enormous and can be summarised as follows. First, an increasing level of exports has loosened the foreign exchange constraint. This in turn has enabled China both to improve its balance of payments position and to absorb foreign resources including imports of capital goods. Second, greater contact with foreign competitors has exerted pressure on Chinese export industries to increase efficiency and to improve the quality of their products. Third, trade expansion has been conducive to greater resource utilisation in China: export growth has led to resources being reallocated to the most efficient sectors of the economy in which China has a comparative advantage. Finally, export growth has promoted the emergence of greater economies of scale for Chinese firms, which in turn tends to raise productivity (Wang 1993:73; Lardy 1992:8 and Song 1996b:194). Based on these points, it can be said that the rapid growth of exports has positively contributed to economic growth in China (see Figure 4.1)..$^{13}$

\section{Emerging overseas investments}

With trade reform and much deepened integration with the world economy, capital has started to chase investment opportunities offshore. Other factors that contribute to an increase in China's overseas investment include high levels of domestic savings and international reserves, China's comparative advantage in certain areas and competitive pressures on the world market. By the end of 1998, a total of 5666 enterprises had invested overseas, with contracted total investment reaching US $\$ 6.33$ billion. Investment areas include manufacturing, trade, resource exploration, processing and assembly, transport, tourism and food (People's Daily, 1 March 1999:2).

In summary, trade reform over the past twenty years has played a dual role in the reshaping of the Chinese economy. First, trade liberalisation has, through the improved allocation of domestic resources, enlarged the external economy, raised the standard of living and strengthened the national economy. Second, trade reform and liberalisation have, through the requisite changes to the domestic economy, become an impelling force to domestic reform. 
Trade reform has been accompanied by a gradual reduction of domestic distortions, although continued distortions still limit the scope and extent of further improvement in the allocation of domestic resources. The result is a better utilisation of production resources.

The process of trade liberalisation has been periodically disrupted by macroeconomic instabilities (mainly in the form of excess demand, high inflation and the imposition of government controls over trade) in the 1980 s and the early 1990 s. A policy implication is that a prerequisite for a successful trade liberalisation program is the maintenance of macroeconomic stability.

Finally, trade reform had been both incremental and ad hoc in the 1980s (Lardy 1992:3). But the gains from the transition to a more open economy are evident. Deeper and increased participation in the world economy gradually paved the way for the introduction of more comprehensive reform programs, illustrated by the reform measures taken in the mid 1990s.

\section{New challenges}

New challenges facing the government in deepening trade system reform include both internal and external constraints.

\section{Domestic constraints}

In the 1980s and early 1990s, China experienced several periods of excess demand leading to domestic inflation that tended to undermine the opening of China to the world economy. Excess demand led to a deterioration of the trade account and to the imposition of more ad hoc controls on trade to prevent a depletion of China's foreign exchange reserves (Lardy 1992:139). However, since the end of 1997, China has faced a completely different but equally devastating situation, namely excess supply, which has been manifested by weak domestic demand. ${ }^{14}$ Weak demand has been compounded by over-capacity in many industries, poor economic performance (particularly of SOEs), financial risks, increasing unemployment and a slowdown of economic growth.

Past experience shows that a smooth transformation of economic and trade system requires macroeconomic stability. It is also conditional on relatively high economic growth, though neither too high nor too low economic growth rates are the most ideal for reform programs. This 
implies that growth targets and reform objectives are not always compatible. For example, a rapid growth rate may sacrifice the progress of reform if it arises from low quality and inefficient growth. On the other hand, reform objectives have to be balanced with other broad objectives of a transitional economy such as social stability. There is also a time dimension to the balancing act between reform and growth, that is, achieving a balance between short, medium and long-term objectives. The current domestic constraints to reform reflect the fact that the Chinese economy has reached a stage where a more delicate balance between growth and reform targets needs to be sought and maintained (Song 1998c:7).

Figure 4.1 Contribution of exports to economic growth, 1990-98 (percentage points)

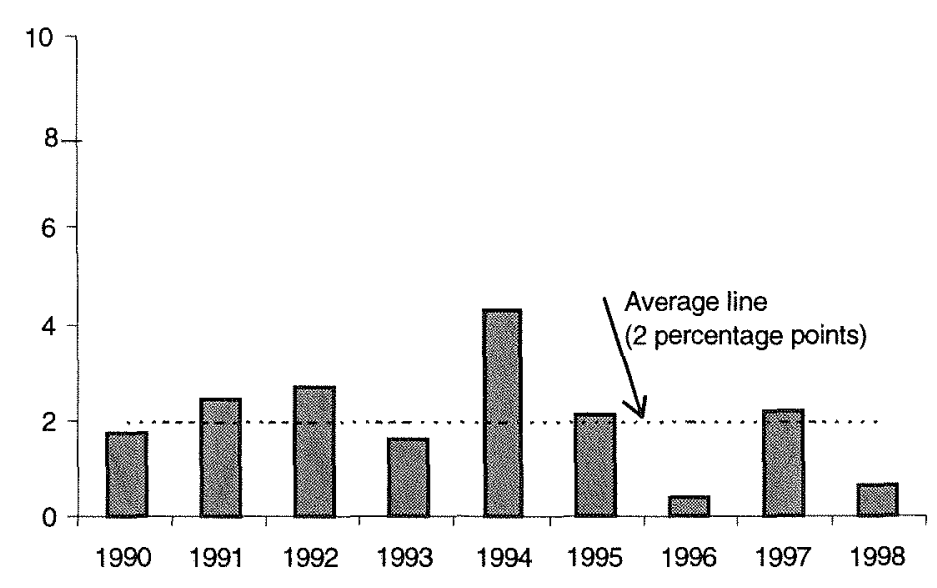

Source: Author's calculations based on United Nations Trade data at international Economic Databank, The Australian National University, Canberra; State Statistical Bureau, 1998. Statistical Yearbook of China, China Statistical Publishing House, Beijing. 


\section{External constraints}

Weak domestic demand and a slowing of trade growth due to the financial crisis in East Asia have posed new challenges to the ongoing trade system reform and liberalisation program in China. Newly released figures show that China began to feel the impact of the financial crisis in 1998; in particular its export growth lost momentum throughout that year. China's overall foreign trade volume fell 0.4 per cent in 1998-the first decline in 15 years-to US $\$ 323.9$ billion. Exports inched up 0.5 per cent from 1997 to US $\$ 183.8$ billion, in the same year recording the lowest annual growth rate since 1983, while imports were down 1.5 per cent to US $\$ 140.2$ billion (China Daily, 24 February 1999).

To combat weak domestic demand and the deterioration of external trade, the government has adopted more expansionary monetary and fiscal polices, but refrained from using exchange rate policy, which had been an effective means of adjusting the over-valued RMB exchange rate throughout the reform period before the Asian crisis.

Previous experience shows that exchange rate devaluation plays an important role in the process of trade liberalisation. This is because

a real devaluation is crucial for stimulating the growth of exports that, in turn, facilitates the liberalisation program. Particularly when the degree of protection of import competing industries is reduced as part of a trade liberalisation package, the expansion of exports is helpful in avoiding balance of payments pressures that would otherwise tend to undermine the liberalisation program (Lardy 1992:115).

A large trade surplus and capital inflows continued to produce a strong performance from China's balance of payments in 1998, but the ongoing slowdown of export growth is of concern.

It is important to note that trade reform and liberalisation have led to a rapid expansion of foreign trade in the past twenty years. But it is also important to recognise that sustained growth of trade will result from deepening trade system reform. From this perspective, maintaining the growth momentum of foreign trade in the next few years will be crucial to the success of the ongoing trade system reform at this stage of development.

China's export prospects will continue to rely on strong world demand and further improvements in productivity and competitiveness within 
the economy (Song 1998a:19). There will be increasing pressure for China to upgrade its industrial structure, produce high value-added and high quality products and further expand its trade destinations. China's imports will depend on the growth of national income and industrial outputs as well as the success of reform measures to further open up the domestic market.

\section{Unfinished tasks}

There are still some tasks to be completed before China can enjoy an open, transparent and efficient trade system. Some of the constraints outlined in the previous section make it even harder for the government to accomplish these tasks.

\section{Accession to WTO}

After twenty years of economic reform and nearly 13 years of endeavour, China is yet to be admitted to the WTO. There is general agreement that China needs the WTO in order to obtain more benefits from trade and carry out further its reform programs and the WTO needs China in order to strengthen the multilateral trade system. But substantial differences remain on the conditions under which China is to be admitted to the organisation.

It is true that China has made great achievements in developing its foreign trade over the past 20 years without being a member of GATT/ WTO. But this fact does not and should not diminish the urgency of resolving the accession issue for China for two main reasons. First, China has come to a stage where more comprehensive reform programs are needed. China's accession to WTO would be conducive to enhancing such reform programs addressing the institutional, economic and legal frameworks underlying the Chinese system. Second, as a large trader and big emerging market, China's participation in the WTO before the new round of trade negotiations begins would help facilitate the trade organisation's ongoing and forthcoming negotiations on many trade and related issues such as anti-dumping, environmental protection, agricultural protection and service trade, and would therefore strengthen the effectiveness of the WTO.

A proper solution to resolving China's membership issue would be to 'allow relatively long phase-in periods for dismantling the barriers 
protecting China's most sensitive sectors, but to insist on more rapid reduction of trade barriers in less sensitive sectors and immediate reforms with respect to transparency, trading rights, and other systemic features of China's trading system' (Lardy 1996:180).

\section{Liberalisation of the capital market}

China has opened its current account but refrained from a quick opening of its capital account because the conditions for capital account liberalisation have not been in place (Song 1998b:115). This position has been further strengthened by the East Asian financial crisis in which the vulnerability of early capital market liberalisation has been shown. 'It is a lesson of the crisis that the strengthening of financial institutions should proceed on an early timetable, in advance of complete convertibility on capital account' (Garnaut 1998:357). This is particularly true for China, whose financial institutions are in need of an overhaul (see Hasenstab, Chapter 6).

Meanwhile, considering the need as well as benefits of opening its capital account, China continues to adhere to the principle of making the RMB fully convertible in the future. A practical solution is to treat capital account liberalisation not as instantaneous but as a gradual process, analogous to the methods used in the opening of the current account (Hanson 1995:401). By adopting this approach, China can mimimise some of the side effects of the mismatch between current and capital account liberalisation, such as adjustment costs.

For example, the liberalisation process could start by relaxing controls over long-term capital inflows ahead of short-term capital inflows. Similarly, the relaxation of controls over foreign direct investment should be preceded by relaxing controls over portfolio capital inflows; trade financing preceded by financial loans; stock transactions preceded by security transactions. Financial liberalisation, especially the opening of the capital market and the relaxation of short-term capital flows, should be implemented last in the whole process of realising full convertibility of the capital account (Chen 1998b:359). 


\section{The role of the private sector}

Over the past 20 years, trade reform has focused more on shifts in trade policy and the behaviour of SOEs in production and trade. While increasing numbers of SOEs were granted direct trade rights, private enterprises continued to be denied these rights. Many of these private enterprises are export-oriented firms and they have had to export their products via enterprises with foreign trade rights.

Due to the restructuring of the economy, especially ownership reform, private enterprises in China are emerging as a new growth source in the economy. But their role in China's foreign trade is still hampered by slow progress in granting them much-needed foreign trade rights. Further difficulties faced by private firms include obtaining finance.

Things began to change in early 1999. As part of reform measures to change the way in which China manages its trade activities, and to encourage private enterprises to participate more actively in foreign trade, 20 private manufacturers were granted export and import rights in early January 1999. This was the first time since 1957 that nonpublic enterprises were entitled to conduct foreign trade independently, setting them on an equal footing with their state-owned and collectively owned counterparts. The much lower operation costs, more flexible trading methods and greater financial incentives of the private firms will put considerable pressure on SOEs (China Daily, 5 January 1999).

Just one month later, in February 1999, another 41 private enterprises were granted foreign trade rights (China Daily, 10 February 1999). The government's relaxation of control over trade rights for private firms at the beginning of 1999 represents a significant step in the reformation of the trade system. However, much more needs to be done to nourish this rapidly emerging and dynamic sector of the economy.

China's private sector emerged in the late 1970s and has grown quickly in the past 20 years. By the end of 1997, there were a total of 960,000 registered private firms in China, employing13.49 million workers. The share of the non-state sector in total GDP increased from 0.9 per cent in 1978 to 24.2 per cent in 1997 (People's Daily, 23 January 
1999). But, in a country where production and commercial activities have been dominated by SOEs for decades, there is still much discrimination against private enterprises in areas such as business registration and financing. It remains a big task to allow direct and wider participation by private firms in China's foreign trade.

\section{Need for comprehensive reform}

The ultimate goals of trade system reform cannot be achieved without the success of more comprehensive reform of many parts of the Chinese economy including the financial and banking systems, fiscal system, taxation system, price system, enterprise system and bureaucratic system. The experience of trade system reform over the past twenty years suggests that lack of reform in other areas could slow the progress of trade reform. For example, further reduction of government protection has been restrained by the lack of progress in reforming many inefficient SOEs. Another example is that the incompatibility of China's enterprise system, contract system, taxation system and personnel management system with standard international practice has hindered the implementation of some trade reform measures such as national treatment.

Equally important is to have in place a set of effective and efficient macroeconomic policy mechanisms aimed at managing an open economy in an indirect way. Such policies include monetary policy, fiscal policy, exchange policy and trade policy. With such mechanisms in place, China's economic activities in general and foreign trade in particular will eventually be free from direct administrative controls and interference. However, building these policy mechanisms hinges on a gradual but sustained development of markets (for goods as well as factors of production). At present, markets are expanding but not sufficiently for indirect policy mechanisms to be effective. There remains much room for government direct controls and interference over economic and trade activities.

Building a modern trade system also requires a transparent and effective legal framework under which new laws and regulations can be established and enforced. To become more integrated with the world economy and continue to benefit from such integration, China needs to address issues such as the protection of intellectual property rights (patents, trademarks, industrial designs and publications). 
Progress has been made with regard to the establishment of regulations governing trade activities. For example, the Trademark Law came into force in March 1983, the first Patent Law became effective in April 1985, the Copyright Law came into force in June 1991 and the Law on Protection Against Unfair Competition became effective in December 1993. China also issued the legislation of border protection in September 1994. Under this legislation, goods that infringe on intellectual property rights are prohibited from being imported and exported (Huang 1996:223).

But problems remain. Huang (1996) summarises them as a lack of force behind law enforcement, local protection of copyright infringements, insufficient enterprise awareness of intellectual property rights and intellectual property rights protection, insufficient consumer awareness of intellectual property rights protection, lack of professional personnel, and incompleteness of legislation. Resolution of these issues is a necessary condition for China's trade system to effectively operate on a sound legal basis.

In summary, progress has been made on all fronts but China still faces formidable tasks in fully accomplishing reforms.

\section{Conclusion}

Deepened domestic reform and continued trade liberalisation will provide an institutional guarantee for accomplishing these unfinished tasks. In particular, further reforms are needed to carry out more extensive structural adjustments, enhance competition, reduce the protection of non-tariff barriers, further open up the service sector, including financial services, to foreign competition and increase the transparency of the trading system particularly the import system, ${ }^{15}$ and build the rules-based trade system. APEC trade liberalisation and China's accession to the WTO offer two important vehicles for China to fulfil these tasks.

\section{Notes}

- Comments made by Ron Duncan are gratefully acknowledged.

1 See the discussion in Shi (1998:158).

2 Part of this section is taken from the section of trade system reform in China in Song (1996b) with updating. 
${ }^{3}$ Processing trade continues to account for a large proportion of China's foreign trade.

${ }^{4}$ Some studies such as Shi (1998) and $\mathrm{Li}(1996)$ treat this period as part of stage one of the trade system reform.

${ }^{5}$ There are still debates about whether the contract system was a necessary step in reforming SOEs or whether it actually went astray and therefore delayed the reform of SOEs (see Renwei, Chapter 9).

${ }^{6}$ When China established an import licensing system in 1988, it covered 53 commodities accounting for about one-third of China's total imports. In 1992, the total number of commodities that were subject to import licensing was reduced by 16 (Shi 1998:166).

${ }^{7}$ By the end of 1993 , China publicised 47 internal documents on imports and exports which were still in use, abandoned 122 such documents and promised to publicise all internal documents within one year (Shi 1998:166).

${ }^{8}$ This stage of reform will probably end with China's accession to WTO and China will enter a new phase of reform thereafter.

${ }^{9}$ In 1998, the government closed down the remaining foreign exchange swap markets.

${ }^{10}$ For example, by the end of 1997 the number of enterprises that had rights for conducting foreign trade reached 13,000 (Shi 1998:169).

${ }^{11}$ From January 1999 , the government planned to extend the trade registration system to 6800 large industrial enterprises (People's Daily, 1 March 1999).

${ }^{12}$ Mandatory planning for exports was abolished in 1991; at the same time state budgetary subsidies to foreign trade corporations for exports were also eliminated. By 1992, planning for imports covered only 11 broad product groups, accounting for about 18 per cent of total imports. It was further reduced to about five broad product groups in 1993 (see Tseng et al. 1994:4).

${ }^{13}$ On average, exports contributed 2 percentage points to the average real GDP growth of 10 per cent for the period 1990-98.

${ }^{14}$ By January 1999, the benchmark retail price index was in negative territory for the $16^{\text {th }}$ consecutive month. It sank by 2.8 per cent in that month, compared to a 2.6 per cent fall for 1998 as a whole (China Daily, 15 February 1999).

${ }^{15}$ After China's accession to the WTO, the coverage of non-tariff barriers would fall dramatically, according to the Chinese government. After full phase-in, the only significant remaining measure would be state trading, mainly in agriculture, which is covered by special provisions under the WTO (World Bank 1997e:15). 